Article

\title{
Impacts, Systemic Risk and National Response Measures Concerning COVID-19-The Island Case Studies of Iceland and Greenland
}

\author{
David Cook ${ }^{1,2, *(1)}$ and Lára Jóhannsdóttir ${ }^{3}[0$ \\ 1 Environment and Natural Resources, Faculty of Economics, University of Iceland, Gimli, Sæmundargötu 2, \\ 102 Reykjavík, Iceland \\ 2 Faculty of Environment and Life Sciences, University of Iceland, Gimli, Sæmundargötu 2, 102 Reykjavík, Iceland \\ 3 Environment and Natural Resources, Faculty of Business Administration, University of Iceland, Gimli, \\ Sæmundargötu 2, 102 Reykjavík, Iceland; laraj@hi.is \\ * Correspondence: dac3@hi.is
}

Citation: Cook, D.; Jóhannsdóttir, L. Impacts, Systemic Risk and National Response Measures Concerning COVID-19-The Island Case Studies of Iceland and Greenland. Sustainability 2021, 13, 8470. https:// doi.org/10.3390/su13158470

Academic Editor: John Rennie Short

Received: 23 June 2021

Accepted: 27 July 2021

Published: 29 July 2021

Publisher's Note: MDPI stays neutral with regard to jurisdictional claims in published maps and institutional affiliations.

Copyright: (C) 2021 by the authors Licensee MDPI, Basel, Switzerland. This article is an open access article distributed under the terms and conditions of the Creative Commons Attribution (CC BY) license (https:// creativecommons.org/licenses/by/ $4.0 /)$.

\begin{abstract}
The Arctic is a remote region that has become increasingly globalized, yet it remains extremely vulnerable to many risks. The COVID-19 pandemic presented new challenges to the region. Using the search, appraisal, synthesis and analysis (SALSA) approach to conduct a metasynthesis of the academic and grey literature on the impacts of the pandemic, an assessment is conducted of the types of risks that have been presented by the COVID-19 pandemic, the scales, and the national response strategies for mitigating the risks. Two case studies are explored: Iceland and Greenland, island nations that exemplify the extremes of the Arctic and reliance on tourism, a sector that was nearly entirely suspended by the pandemic. An evaluative matrix is employed which combines five different scales of risk — nano, micro, meso, macro and cosmic — with a sustainability categorization of impacts. The risks of the pandemic cut across the respective scale and categories, with the potential for macro-scale events (systemic risk) to unfold linked to economic spillover effects driven by the curtailment of tourism and various supply chain delays. Both Iceland and Greenland have exemplified risk mitigation strategies that prioritize health over wealth, very strictly in the case of the latter. Strict border controls and domestic restrictions have enabled Iceland and Greenland to have much lower case and death numbers than most nations. In addition, Iceland has led the way, globally, in terms of testing and accumulating scientific knowledge through genetic sequencing of the virus. The academic contribution of the paper concerns its broadening of understanding concerning systemic risk, which extends beyond financial implications to includes sustainability dimensions. For policymakers and practitioners, the paper highlights successful risk mitigation and science-based measures that will be useful for any nation tackling a future pandemic, regardless of whether they are island states, Arctic nations or another country.
\end{abstract}

Keywords: risk; resilience; pandemic; prioritization; risk management; Arctic

\section{Introduction}

Arctic communities are often remote, resource dependent and based upon a mixture of monetary, mixed and non-monetary economies [1,2]. They rely on complex socio-ecological systems $[2,3]$ which are especially vulnerable to risk, lacking resilience and adaptive management capacity [4,5]. These risks occur across various scales and are multifarious, including but not limited to climate change [6-8] and severe weather events [9], the potential spread of infectious diseases [10], lack of economic diversity and insufficient access to human capital [11], and the potential for environmental accidents to severely degrade the resources on which communities depend $[12,13]$.

In 2020, a new risk presented itself not just to the Arctic, but to the whole world-the COVID-19 pandemic. Increasingly globalized, the Arctic is no longer a distinct region in the 
north, a separate sphere divorced from people living in more southerly latitudes. Tourists come and go, labour is highly mobile and supplies of food and goods are shipped to Arctic ports daily. The World Economic Forum (2020) highlighted a series of economic risks of global concern due to COVID-19, including: prolonged recession; surge in bankruptcies; failure of whole sectors to recover; high levels of structural unemployment, especially among young people and women; tighter restrictions on cross-border flows of people; weakening fiscal positions of national economies; and protracted disruption of global supply chains [14]. These are all likely to be applicable to Arctic states; however, the incidence of risk in the Arctic is often of greater degree than the rest of the world due to special vulnerabilities linked to nature and resource reliance, remote locations with tightly woven communities and people-reliant economies [1,13,15].

Arctic island states exemplify the sustainability challenges specific to the region. This paper aims to evaluate the type, character and extent of the risks pertaining to the COVID19 pandemic. The analysis involves two case studies of Iceland and Greenland, vulnerable island nations which exemplify the issues of remoteness, limited infrastructure in remote areas, relatively undiversified economies reliant on tourism and resource dependency that are commonplace in the Arctic region [1,2]. Three research questions (RQ) are explored, which are as follows:

1. What are the various risks that have been presented by the COVID-19 pandemic in the case studies?

2. What scales of risk relate to the aspects identified in RQ1?

3. What have been the national response strategies to the pandemic in the Arctic and how effective have these been at mitigating the risks?

The nano-micro-meso-macro-cosmic framework used in Jóhannsdóttir and Cook (2019) [12] is applied to determine the types and scales of risk confronted by Iceland and Greenland during the COVID-19 pandemic to date, and the potential for a systemic risk event to unfold covering multiple dimensions. The potential for a systemic risk event has already been discussed in the academic literature with respect to COVID-19; however, as per the World Economic Forum's assessment, such studies tend to focus overwhelmingly on the economic implications of the pandemic [16-18]. A narrow evaluative focus on systemic risk has also been reported in other literature $[12,13,19]$. In this paper, in order to understand the broader aspects of systemic risk events and their potential to undermine human wellbeing [20], risks are further categorized according to the dimension of sustainability to which they relate: economic, business, environmental and socio-cultural. In addition, the framework considers whether the risk aspect has any policy-related consequences. These are essential to answering the second and third research questions, gaining understanding of the links between risks, implications, policy responses and the extent that the problem has been mitigated.

This paper is structured as follows. Section 2 provides background information, including a brief overview of COVID-19, and introduction to types of risk and scales of risk. Section 3 details the method of analysis that were applied in this study. Section 4 provides a combined results and discussion, outlining the types of risk observed in Iceland and Greenland, the scales of risk, the success of mitigation measures, and the extent to which these can be generalized to other locations around the world. A matrix is presented of scales of risk deriving from COVID-19 versus sustainability impacts, which constitutes the main theoretical contribution of the paper in response to RQ2.

\section{COVID-19 Background and Overview of Risk and Scales of Risk}

\subsection{The COVID-19 Pandemic}

COVID-19 constitutes the first global pandemic in more than 100 years [14]. At the time of conducting this research, there have been more than 170 million cases diagnosed worldwide and just over 3.5 million deaths ascribed to the virus [21]. These figures are almost certainly underestimates given that there is chronic undertesting around the world. Cases have been reported in almost every country in the world, and even on Antarctica [22] 
and Mount Everest [23]. Although the effects are ongoing, within two months of the pandemic being announced, populations in 120 countries had been subjected to lockdowns to control the virus and ensure that healthcare services were not overwhelmed [14]. The full extent of the economic impacts is not yet known, but it is estimated that 500 million additional people are at risk of being placed into poverty [24].

\subsection{Risk and Systemic Risk}

A 'risk' can be defined in many ways. For the purposes of this paper, we will use the definition set out by the Intergovernmental Panel on Climate Change, which describes the concept as the "potential for adverse consequences from a hazard for human and natural systems, resulting from the interactions between the hazard and the vulnerability and exposure of the affected system" [25] (p. 33). This definition is especially apt in the context of the COVID-19 pandemic, given its acknowledgement of a hazard presenting systemic consequences and potentially multiple consequences for human well-being.

Definitions of systemic risk also abound in the literature. There are those that focus very heavily on triggers or tripping points, from which there are likely to be a cascade of negative economic implications. Schwarcz referred to the potential for "a chain of bad economic consequences" and "significant losses to financial institutions or substantial financial-market price volatility" [26] (p. 198). Certainly, the definition of [26] accords well with the suddenness of the COVID-19 outbreak and the economic impacts of its devastating spread around the globe. However, it has limited applicability to understanding the full and diverse implications of the COVID-19 pandemic, focusing on risks to financial systems as opposed to risks within a broader system. There thus needs to be a recognition of the endogenous effects of the COVID-19 pandemic.

The endogenous characteristics of systemic risk ensure that feedback loops between systems and portfolios should be considered, since market and institutional system risk is not inseparable $[27,28]$. It is because of interlinkages between and across systems that systemic risk presents the potential for the entire breakdown of systems rather than individual parts or components, leading to widespread consequences [29,30]. As has been stated, many of these effects will be economic [14,16-18,26]; however, a purely economic analysis underrepresents the multidimensional ramifications of a global shock such as the COVID-19 pandemic. Evaluations of systemic risk focused only on economic perturbations may constitute too limited a depiction, and there is thus a need to consider connected impacts, including environmental, social, financial and technological aspects $[27,28]$.

There is evidence that systemic risk events are relatively common, albeit most occur on a spatial scale that is smaller than the global incidence of the COVID-19 pandemic. There are an array of examples involving failures of socio-technological systems, which have had multiple sustainability implications not limited to the undermining of economic prosperity [30]. These include the Piper Alpha disaster in 1988, the Northeast Blackout in the parts of the Northeastern and Midwestern United States and the Canadian province of Ontario in 2003, the space shuttle disaster in 2003, the BP Deepwater Horizon oil spill in 2010, and the Volkswagen Emissions Scandal in 2016. The literature also includes a comprehensive, case-study based analysis of the potential systemic risk implications of oil spills in the Arctic [12], and a similar study focused on cruise ship incidents in this region [13].

\subsection{Scales of Risk}

This study relies upon the pyramidic scales of risk depicted by [31]. This scale has five tiers ranging from the nano to the cosmic level, as illustrated in Figure 1, with each of these briefly explained in Table 1 . These have been used in previous evaluations of systemic risk in an Arctic context [12,13]. The explanations in Table 1 are sourced from conceptual descriptions in $[12,13,31]$. 


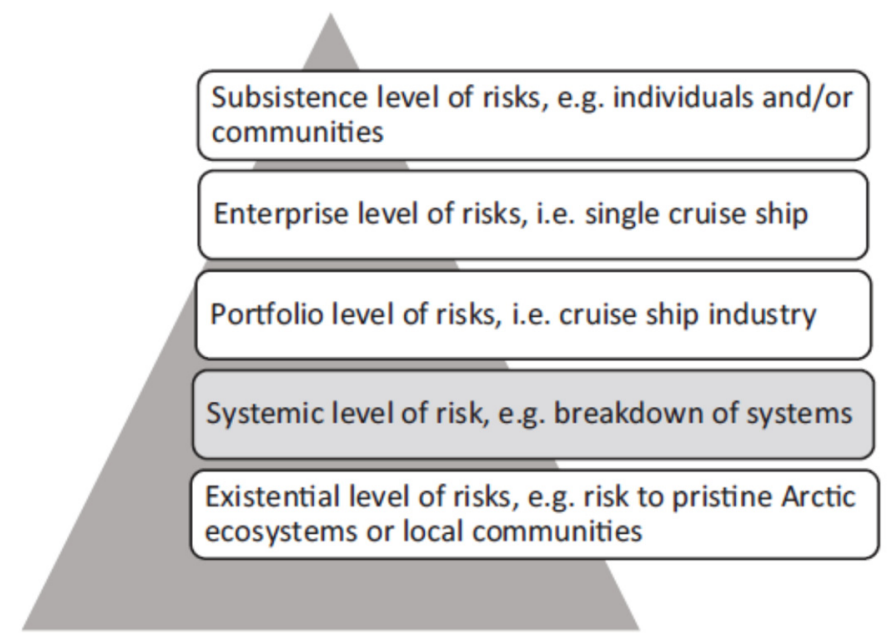

Figure 1. Business model transformation scaling process.

Table 1. Explanation of scaling progression.

\begin{tabular}{ccl}
\hline Description of Risk & Scale of Risk & \multicolumn{1}{c}{ Explanation } \\
\hline Career & Nano & $\begin{array}{l}\text { Risk to individuals, including investors, that focus on } \\
\text { maintaining business-as-usual. }\end{array}$ \\
\hline Enterprise & Micro & Risk to commercial enterprises. \\
\hline Portfolio & Meso & Risk to investment portfolios. \\
\hline Systemic & Macro & $\begin{array}{l}\text { A combination of linked market, investment and } \\
\text { institutional failures, with sustainability ramifications. }\end{array}$ \\
\hline Existential & Cosmic & $\begin{array}{l}\text { Problems that present an existential risk, such as } \\
\text { climate change or droughts. }\end{array}$ \\
\hline
\end{tabular}

The report of the WEF (2020) concluded that the COVID-19 pandemic had led to a series of interlinked manifestations. These were characterised as: economic shifts; sustainability setbacks; technology dependence; and societal anxieties [14]. This study applies a similar categorisation but recognises that 'sustainability setbacks' is a broad delineation requiring more nuanced analysis that goes beyond the classical three pillars of sustainability: economic, environmental and socio-cultural.

The breadth of the impacts described in the WEF (2020) report went far beyond the nano, micro and meso level of risks, and were demonstrative of a systemic risk event. Some may argue that the COVID-19 pandemic constitutes a cosmic level event, however, it is arguable whether it presents an existential threat of the same scope as the severest effects of climate change, and vaccination programmes are a form of mitigation. Impacts such as rising sea levels, wildfires and devastating droughts cannot be mitigated for through preventative event, demanding adaptation and, in some cases, the entire relocation of communities. Livelihoods and sustainability of communities and regions is permanently compromised in a cosmic level event.

\section{Case Studies, Materials and Methods}

\subsection{Selection of Case Studies and Their COVID-19 History}

The two case studies of Iceland and Greenland were selected for analysis in this paper. This is because their island status exemplified the challenges and risks specific to many Arctic nations-low and remote populations (circa 368,000 in Iceland and 56,000 in Greenland), a reliance on natural resources for livelihoods, economic monotony closeknitted communities and limited critical response capacity in the case of crises such as pandemics, particularly outside of the capital cities of Reykjavík and Nuuk. 
Iceland experienced its first case of the COVID-19 pandemic in Reykjavík at the end of February 2020. By 30 May 2021, the total number of cases in Iceland was 6576, of which 6505 had recovered and 30 deaths had occurred [32]. Although these numbers are very small in terms of the global total, the infection rate per inhabitant has at times been one of the highest in the world [33]. Since this time, in terms of transmission prevention and borders controls, the Icelandic approach has consistently focused on: (a) home-based quarantine for inhabitants, very high levels of polymerase chain reaction (PCR) testing and tracing, various limitations on the size and type of public gatherings (including closure of swimming pools, gyms, schools, entertainment venues and many business related to the tourism sector), and widespread mandatory use of sanitiser and mask wearing in buildings accessed by the public; and (b) strict double testing of visitors and returning residents to Iceland, with a five to six days quarantine in between [34,35]. The latter measure has recently been adapted so that tourists with an approved certificate of vaccination are allowed into Iceland following one negative COVID-19 test on arrival and a maximum of a one-day quarantine, whilst non-vaccinated tourists must be tested twice and quarantine for five days in a pre-determined hotel, or in other places if accepted by the authorities [36]. Such measures have largely been very successful, with the European Centre for Disease Prevention and Control frequently identifying Iceland as the only 'green' European nation in its weekly reports, which have been published since 17 December 2020 [37].

Greenland's first COVID-19 infection occurred in Nuuk in March 2020. On 30 May 2021, a total of 40 cases had occurred in Greenland, 33 of whom had recovered and 7 were active cases [21]. The nation is one of only a handful to have experienced cases and yet zero fatalities. Domestic measures have also focused heavily on gathering restrictions, PCR testing, tracing, home quarantining and use face masks in public spaces [38,39]. For a time at the start of the pandemic, internal flights were also greatly restricted [40] and sales of alcohol in Nuuk prohibited [41]. Apart from for key workers who had to self-isolated for fourteen days, a strict travel ban applied from 1 January 2021 until 3 May 2021 [39]. At this point, the Government of Greenland permitted up to 600 travellers to arrive each week provided they had a negative COVID-19 test before boarding and were quarantined for five days upon arrival before being retested [42]. However, a strict lockdown in Nuuk ensued once again at the end of May 2021 when a cluster of six new cases developed, linked to a construction firm [43].

\subsection{Data Collection and Analysis}

Data was collected from March to May 2021. The exploration of the literature was conducted using the search, appraisal, synthesis and analysis (SALSA) framework. One of the advantages of using the SALSA method in this study is that it has its roots in systematic reviews carried out in health sciences [3] and that the flexibility of its four-stage process has been demonstrated recently in a variety of contexts, including literature reviews on Arctic and glacier ES [3,44], the cultural ecosystem services of geothermal landscapes [45], and the identification of indicators of sustainable energy development [46].

The stages in the method, purpose of each stage and actions undertaken were as follows:

\section{Search}

- This stage sought to identify the most significant items with respect to the risks, impacts and policy responses in Greenland and Iceland. First, an extensive search was used before the sourced publications were narrowed down in a second stage.

- Initial broad search using terms such as "impacts", "risk", "response", "management" and "mitigation" in conjunction with "Iceland" and "Greenland". Standard BOOLEAN search strings (i.e., AND/OR) were applied in Google and five academic databases (EBSCOhost, Scopus, ScienceDirect, Web of Science and Google Scholar). In addition to publications found using snowball technique, this resulted in a very large set of journal articles, news reports and analyses of 8300 in total, many of which were not relevant to this study. 
- Narrowed search using combinations of initial search terms in conjunction with scale and sustainability terminology. The former did not use the precise scale terms, but rather words of association e.g., "unemployment", "support" and "income" for the career risk scale. After removing duplicate studies and verifying the specifics of the locations referred to, this resulted in a total of exactly 100 publications and sources of relevance to this study.

\section{Appraisal}

- This stage aimed to code and thematize the content in the 100 publications.

- All publications and sources were read in entirety and their main sustainability impacts summarised. These categories had been partially pre-determined based on the identified risk themes in [12,13], with the health, ethical, and science and education categories added. The impacts were also grouped according to whether they were general to the Arctic, Icelandic or Greenlandic specific impacts.

3. Synthesis

- Tabular analysis (Table 1) was used to further categorise the sustainability-related risks in accordance with the nano, micro, meso, macro and cosmic framework.

- Impact types (risk and sustainability) and supporting references were then studied further in order to decipher core themes, patterns and variations in relation to the case studies. These are outlined in Sections 4.1 and 4.2 of this paper.

\section{Analysis}

- Deep analysis of Table 1 and underpinning studies and data.

- An evaluation of key outcomes and policy responses by both Greenland and Iceland. These are described in Section 4.3 of this paper

\section{Results and Discussion}

Table 2 presents the outcome from the SALSA processes. The specific issues are then synthesised in accordance with (a) the impacts and risk in Section 4.1, and (b) the scales of risk in Section 4.2. Section 4.1 responds to RQ1, Section 4.2 to RQ2, and Section 4.3 on policy responses to the risks to RQ3.

Table 2. Categorisation of COVID-19 sustainability impacts and risks-the Arctic, Iceland and Greenland.

\begin{tabular}{|c|c|c|c|c|c|c|c|c|c|c|c|c|}
\hline \multirow[t]{2}{*}{ Sustainability Impact/Risk } & \multicolumn{4}{|c|}{ Arctic General } & \multicolumn{4}{|c|}{ Iceland } & \multicolumn{4}{|c|}{ Greenland } \\
\hline & Nano & Micro & Meso & Macro Cosmic & Nano & Micro & Meso & Macro Cosmic & Nano & Micro & Meso & Macro Cosmic \\
\hline \multicolumn{13}{|c|}{ Economic } \\
\hline $\begin{array}{l}\text { Falling demand for energy } \\
\text { resources and raw materials } \\
\text { e.g., minerals and metals }\end{array}$ & $\checkmark$ & $\checkmark$ & $\checkmark$ & & & & & & $\checkmark$ & $\checkmark$ & $\checkmark$ & \\
\hline High unemployment rate & $\checkmark$ & $\checkmark$ & $\checkmark$ & & $\checkmark$ & $\checkmark$ & $\checkmark$ & & $\checkmark$ & $\checkmark$ & $\checkmark$ & \\
\hline $\begin{array}{l}\text { Economic contraction, reduced } \\
\text { gross domestic product }\end{array}$ & $\checkmark$ & $\checkmark$ & $\checkmark$ & & $\checkmark$ & $\checkmark$ & $\checkmark$ & & $\checkmark$ & $\checkmark$ & $\checkmark$ & \\
\hline $\begin{array}{l}\text { Disrupted supply chains and } \\
\text { decline in key exports, e.g., } \\
\text { fish }\end{array}$ & $\checkmark$ & $\checkmark$ & $\checkmark$ & $\checkmark$ & $\checkmark$ & $\checkmark$ & $\checkmark$ & $\checkmark$ & $\checkmark$ & $\checkmark$ & $\checkmark$ & $\checkmark$ \\
\hline $\begin{array}{l}\text { Contraction in mining } \\
\text { operations and reduction in } \\
\text { flyin/flyout workers }\end{array}$ & $\checkmark$ & $\checkmark$ & $\checkmark$ & & & & & & $\checkmark$ & $\checkmark$ & $\checkmark$ & \\
\hline $\begin{array}{l}\text { Loss of local incomes and } \\
\text { tourism revenues, e.g., linked } \\
\text { to cruise ship visitors }\end{array}$ & $\checkmark$ & $\checkmark$ & & & $\checkmark$ & $\checkmark$ & $\checkmark$ & $\checkmark$ & $\checkmark$ & $\checkmark$ & $\checkmark$ & $\checkmark$ \\
\hline $\begin{array}{l}\text { Declining demand for and } \\
\text { availability of food and } \\
\text { cultural products harvested } \\
\text { and created by Indigenous } \\
\text { Peoples }\end{array}$ & $\checkmark$ & $\checkmark$ & $\checkmark$ & $\checkmark$ & & & & & $\checkmark$ & $\checkmark$ & $\checkmark$ & $\checkmark$ \\
\hline
\end{tabular}


Table 2. Cont.

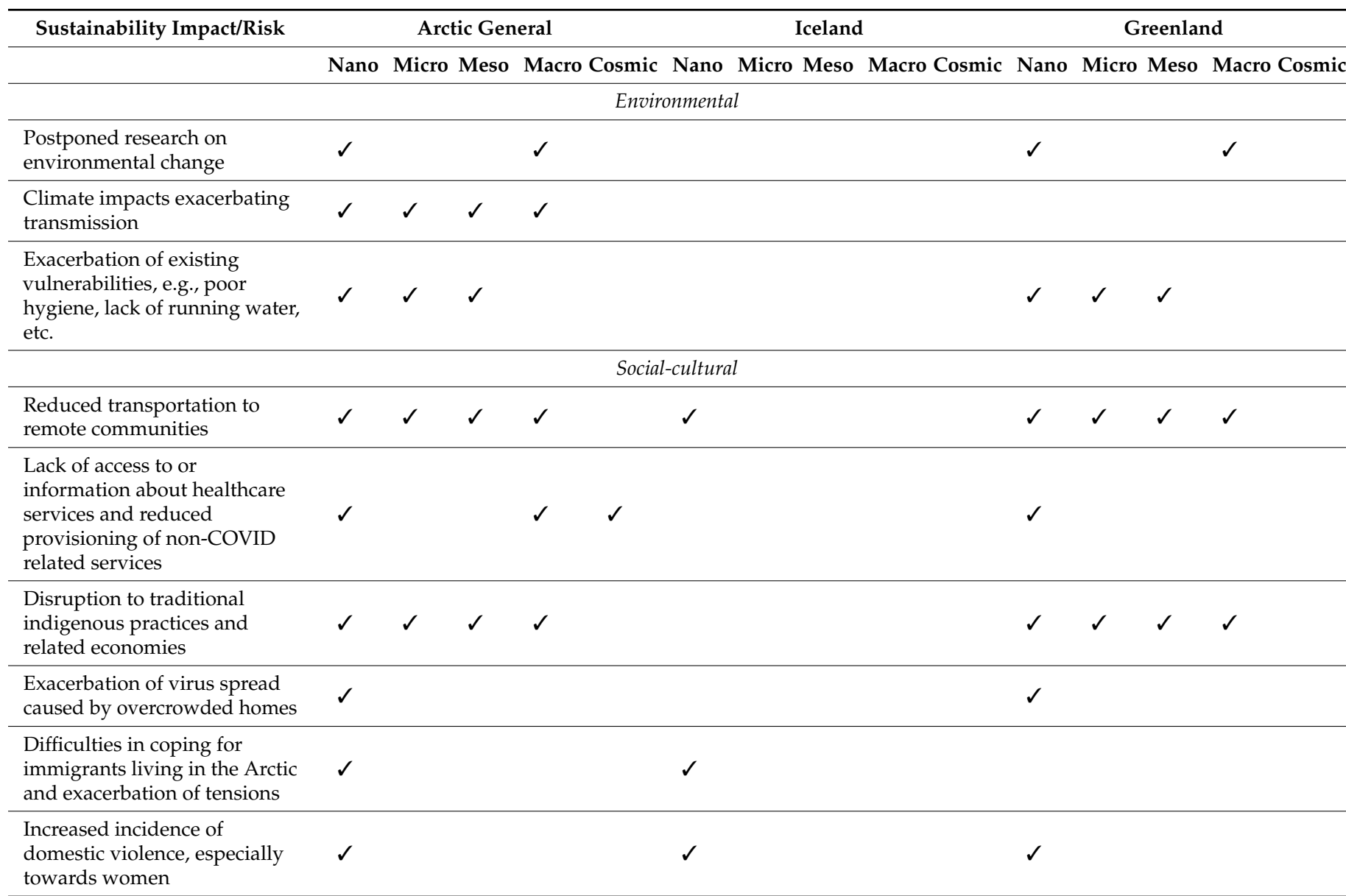

Business

Challenges in working

remotely in communities with poor infrastructure

Increased cases and risks of insolvency

Limited prospects of full

recovery in the next two/three

years in tourism companies

\begin{tabular}{|c|c|c|c|c|c|c|c|c|c|c|c|}
\hline \multicolumn{12}{|c|}{ Ethical } \\
\hline $\begin{array}{l}\text { Inequitable distribution of } \\
\text { funding support, reducing } \\
\text { capacity to manage impacts }\end{array}$ & $\checkmark$ & $\checkmark$ & $\checkmark$ & $\checkmark$ & & & & & & & \\
\hline \multicolumn{12}{|c|}{ Health } \\
\hline $\begin{array}{l}\text { Exacerbation of existing } \\
\text { suicide prevalence }\end{array}$ & $\checkmark$ & & & & & & & & & & \\
\hline $\begin{array}{l}\text { Increased anxiety and poor } \\
\text { mental health }\end{array}$ & $\checkmark$ & & & & & $\checkmark$ & & & & & \\
\hline $\begin{array}{l}\text { Rapid spread of the virus } \\
\text { among vulnerable members of } \\
\text { the community e.g., in care } \\
\text { homes }\end{array}$ & $\checkmark$ & & & & $\checkmark$ & $\checkmark$ & & $\checkmark$ & & & \\
\hline Fragility of healthcare systems & $\checkmark$ & & & $\checkmark$ & $\checkmark$ & $\checkmark$ & $\checkmark$ & $\checkmark$ & $\checkmark$ & & $\checkmark$ \\
\hline $\begin{array}{l}\text { Lack of focus or increased } \\
\text { difficulty in tackling issues to } \\
\text { do with hygiene, sanitation } \\
\text { and drinking water }\end{array}$ & $\checkmark$ & $\checkmark$ & $\checkmark$ & & & & & & $\checkmark$ & $\checkmark$ & $\checkmark$ \\
\hline
\end{tabular}


Table 2. Cont.

\begin{tabular}{|c|c|c|c|c|c|c|c|c|c|c|c|c|c|}
\hline \multirow[t]{2}{*}{ Sustainability Impact/Risk } & \multicolumn{5}{|c|}{ Arctic General } & \multicolumn{4}{|c|}{ Iceland } & \multicolumn{4}{|c|}{ Greenland } \\
\hline & Nano & Micro & Meso & Macro & Cosmic & Nano & Micro & Meso & Macro Cosmic & Nano & Micro & Meso & Macro Cosmic \\
\hline $\begin{array}{l}\text { Slowed vaccine distribution, } \\
\text { prolonging the impacts of the } \\
\text { pandemic and their extent }\end{array}$ & $\checkmark$ & $\checkmark$ & $\checkmark$ & $\checkmark$ & $\checkmark$ & $\checkmark$ & $\checkmark$ & $\checkmark$ & $\checkmark$ & $\checkmark$ & $\checkmark$ & $\checkmark$ & $\checkmark$ \\
\hline \multicolumn{14}{|c|}{ Science/education } \\
\hline $\begin{array}{l}\text { Cancellation of Arctic-focused } \\
\text { research projects and } \\
\text { conferences }\end{array}$ & $\checkmark$ & $\checkmark$ & & & & $\checkmark$ & $\checkmark$ & & & $\checkmark$ & $\checkmark$ & & \\
\hline $\begin{array}{l}\text { Reduced public interaction } \\
\text { and co-production of } \\
\text { knowledge }\end{array}$ & $\checkmark$ & & & & & $\checkmark$ & & & & $\checkmark$ & & & \\
\hline $\begin{array}{l}\text { Distance-learning hurdles for } \\
\text { remote communities with } \\
\text { limited infrastructure }\end{array}$ & $\checkmark$ & $\checkmark$ & $\checkmark$ & & & & & & & $\checkmark$ & $\checkmark$ & $\checkmark$ & \\
\hline
\end{tabular}

\subsection{Impacts and Risks}

In general, in the Arctic, there has been a huge decline in tourism activities [47], and Iceland is demonstrative of the negative economic impacts. Unemployment rates in Iceland have been at their highest levels since 2012, reaching nearly $12 \%$ in June 2020 . There is evidence that the unemployment impact has been unequal in Iceland. An unemployment rate of 26\% was reported on the Suðurnes Peninsula in January 2021, and these rates have at times been $5 \%$ higher among women than men [48]. Nationally, approximately $20 \%$ of foreign individuals living in Iceland have been unemployed [49], higher than their 14\% share of the national population, and reports have found that younger people and immigrants are the worst hit economically by the pandemic [50]. Much of the unemployment has related to the decline in the tourism industry, with foreign visitors reducing from $1,986,153$ in 2019 to 478,510 in 2020, a $75.9 \%$ reduction [51]. The cruise ship component was especially hard hit, with the number of visitors reducing from 549,000 in 2019 to 2300 in 2020, a $99.6 \%$ decrease [51]. This has led to acknowledgement that the Icelandic economy was too dependent on tourism pre-pandemic, which accounted for more than one-fifth of its gross domestic product (GDP), and that diversification is required to minimise the nation's economic vulnerability to a global-scale shock [52].

In Greenland, The Economic Council of Greenland reported significant negative impacts on the tourism and transportations sectors, especially air traffic, although overall economic activity, as measured by GDP, was expected to be almost unchanged from 2019. The number of air passengers on international flights to Greenland was down $86 \%$ in Q2 of 2020 compared with 2019 and the number of bed nights had reduced by $69 \%$ over the same period. Tourism revenues were projected to be down by $67-90 \%$ in 2020 [53]. Air Greenland experienced a deficit in the first six months of 2020 due to border closures and profits before tax for the whole year, reduced from DKK 106.6 M in 2019 to 32.6 M in 2020, a decline of $69.8 \%$ [54]. Impacts on Greenlandic tourism continue to persist well into 2021, with expectations of no cruise ship visits in Greenland until at least July 2021 and maybe 2022 [55]. Fly-in fly-out workers, such as Danes and other foreigners who typically work in Greenlandic tourism, have declined across the Arctic [56]. Moderate negative effects were also reported in other industries, including fisheries and fish processing, and raw materials and energy. These were linked to the falling prices and declining global demand for such commodities, which further decreases the likelihood of oil exploration in the coming years. The Economic Council of Greenland stated an expectation of a decrease in export prices of up to $20 \%$ for Greenlandic fish products for the duration of the pandemic, depending on species and product type. If this prediction is accurate, the price decreases will have major implications for both resource rent tax revenues and other indirect fisheries tax revenues. The 2019 Economic Council report had calculated that a $20 \%$ fall in fish prices would reduce public revenue directly by DKK 232 million (approximately USD 38 million), of which 
resource rent taxes would be down by DKK 113 million, income taxes by DKK 92 million and corporate taxes by DKK 27 million [53].

Impacts on tourism companies have been severe in Iceland, despite financial support from the government. One of the major tourism gift shop chains in Iceland, Geysir, shut their stores in Reykjavík on the first day of February 2021 due to both operational difficulties and the lack of tourists entering Iceland. In addition, the company also laid off all employees [57]. Elsewhere, Arctic shopping, which operates the gift stores of Lundinn, Óðinn, Thor and Jólahúsið in the city centre of Reykjavík, closed all of its shops in Spring 2020 when it became clear that there was great uncertainty about the arrival of tourists [57]. There have also been spillover effects on many commercial operations that depend to some extent on revenue from tourists, including cafes, restaurants, book shops, art and design stores etc. A survey of operations on Laugavegur, the main shopping thoroughfare in Reykjavík, in October 2020 found that $39.6 \%$ of the 192 ground floor businesses were closed. Some of the closures were likely temporary due to strict restrictions on gatherings in bars and pubs at that time, but the majority were completely empty and had been for some time [58]). Many companies had been mandated to close by the Icelandic Government and even some of those that were open were operating under restricted hours.

Supply chain disruptions have been evident, linked to the export of Greenlandic and Icelandic fish. These were impacted quite early by the pandemic due to transportation restrictions (especially concerning air freight) and closures of global markets. Fresh fish and shellfish supply chains were severely impacted by the closure of the food service sectors, such as hotels, restaurants, catering facilities and work canteens. Although Greenlandic GDP was likely unchanged overall, these impacts nevertheless translate into reduced state revenues and capacity to intervene economically to tackle the crisis [59]. Icelandic fish exports also stalled due to the pandemic, particularly in the first half of the year 2020. One company, Iceland Seafood International, reported sales in the first six months of 2020 of EUR 183.2 million, which were down $21 \%$ on the corresponding period in 2019. Normalised profits before tax were down $36 \%$ over the same period [60].

The health-related risks of the pandemic have been severe, mainly due to the lack of critical care infrastructure in hospitals. The medical system in Iceland is small and fragile, with only one hospital in Reykjavík and another in Akureyri providing any intensive and inpatient care. This led to a state of emergency being declared very early in the pandemic in March 2020 in order to prioritise the needs of those who had tested positive for the virus, leading to eight-week delays in elective treatments [32]. Later, in October 2020, a cluster of 58 infections linked to Landakot, the University Hospital's geriatrics department in Reykjavík, led to the immediate recommencement of emergency protocols [61]. The limited care facilities in remote parts of Iceland have been attributed as risk exacerbators-for example, staff shortages in care homes in the remote Westfjords following infections and mandatory quarantining led to a need to fly in additional workers from Reykjavík to cope with an unfolding crisis [62].

Similar issues have been reported in Greenland, whereby the challenge of the remoteness of some communities is likely to delay the initial vaccine distribution plan by around two months, prolonging potential impacts [63]. In addition, an indirect effect of the pandemic has been increased mental turmoil and stress. A student survey was initiated to assess the well-being of students at the University of Akureyri, Iceland during the coronavirus. Of the students that had answered the survey, $85 \%$ either partially or totally agreed that they were experiencing anxiety because of COVID-19. More than $70 \%$ were experiencing symptoms of depression, and $87 \%$ voiced that they were experiencing more stress and that it was affecting their educational performance [64] (Arctic Council, 2020b). The stresses of the pandemic have also been associated with increased incidences of domestic violence across the Arctic, especially towards women [65]. Examples have been reported in both Greenland and Iceland [66,67]. Existing tensions in Iceland between Icelanders and Polish immigrants have increased, with the latter sometimes blamed for the spread of the virus [68]. 
Environmental and social factors such as crowded housing conditions, poor hygienic standards and lack of running water, infrastructure deficits and lack of trained personnel are concerns common to many Arctic communities. Although not reported as issues in Iceland, these factors in Greenland underscore the existing health vulnerabilities of remote Arctic communities and may lead to new challenges [69]. These were reinforced in the early stages of the pandemic when information was not accessible to those who only spoke Greenlandic rather than Danish and Greenlandic. This initially stimulated insecurity among the population [70]. Issues concerning information and consultation in Greenland have also interweaved with the economic consequences of COVID-19 in Narsaq, with concerns that gathering restrictions have prevented a robust and fair public hearing on a new, controversial and long-discussed rare earths and uranium mine [71].

In the area of science and education, consequences of the pandemic have included the cancellation of research projects and both domestic and international conferences dedicated to environmental research [72]. In Iceland, gathering restrictions led to the cancellation of the Arctic Circle Assembly, which had become the largest international forum for debate and discussion about Arctic issues, including the topics of climate change, environmental sustainability, indigenous rights and economic development [73]. COVID-19 concerns led to the cancellation of most US ice core drilling projects on the Greenlandic Ice Sheet during the 2020 field season [74]. Ice cores provide a window into climate and human history that is invaluable in understanding the current climate change crisis. In March, the Danish-run international East Greenland Ice-Core Project (EastGRIP), which studies how ice streams may contribute to future sea-level rise, also discontinued its 2020 season [75].

\subsection{Summary of Results and Scales of Risk}

In Iceland and Greenland, as well as the Arctic in general, multiple risks and impacts relating to the pandemic were identified. These cut across the sustainability dimensions and additional categories, although economic impacts were foremost. Issues concerning jobs, incomes and livelihoods, declines in key industries, such as tourism, and spillover effects to other components of the economy, such as the hospitality and entertainment sectors, were especially prominent $[50,51,53]$. In the case of Greenland, the effects of the virus have been relatively minor in terms of health consequences but economically significant given the extreme remoteness of many communities and reliance on traditional cultural practices and foods [76]. Issues concerning the lack of diversification in the Icelandic economy have been pinpointed, following the constriction of the tourism industry, the nation's main export sector [52,77]. Both Iceland and Greenland rely heavily on export income and other markets have been negatively impacted via supply chain disruptions-fisheries in both nations, and sales of energy resources and minerals in the case of the latter $[59,60]$. Issues concerning reduced access, isolation and association impacts on mental health and well-being have been reported in Greenland [66]. Infrastructure deficiencies have perhaps been underlying factors in business disruption and difficulties in adapting to home working in the case of Greenland [53], which has not been such a factor in Iceland due to the very high levels of connectivity to high-speed internet. Indirect issues have concerned the environment, with poor water infrastructure and sanitation a potential exacerbator in Greenland [69], and the suspension of Arctic-focused fieldwork on globally and regionally important topics, such as climate change [74].

Most of the risks of the pandemic in Iceland and Greenland have presented impacts to individuals, enterprises and industries. Thus, they have been associated with the nano, micro and meso scales of risk. Some impacts, however, are indicative of systemic risk events, whereby economic impacts in one sector spill over into others. Three main economic risks were evident in Greenland: (1) decreased activity level due to forced lockdown; (2) reduced capacity to get the necessary work force to Greenland; and (3) transportation difficulties affecting the delivery of goods [59]. Disrupted supply chains and tourism sectors placed into suspended animation have led to falling demand in the hospitality and entertainment industries, both in Greenland and Iceland [52,53]. Investment in new infrastructure projects 
has been largely curtailed in this period, with spillover effects for developers, contractors and architects [59]. In addition, the need for governments to borrow money to support tourism operators and employees via furlough schemes leads to long-term systemic risks in terms of needing to finance these debts, implying higher tax levels that will potentially constrain macro-economic performance, especially private consumption expenditures. In Greenland, the absence of tourists has systemic consequences for the livelihoods of Indigenous Peoples [78], who nowadays often adopt a mixed economy, selling traditional products to visitors in shops and markets.

Other macro-scale impacts involved declining environmental research, particularly concerning the topic of climate change [73-75]. This has the capacity to delay the accumulation of knowledge about the rate and potential impacts of climate change, at the same time as its impacts are accelerating. This has implications for individuals, businesses, enterprises, investors and national economies the world over, even though the Polar regions are where these changes are observed first and most deeply. Health-related risks also present macro-scale, systemic risk consequences, particularly due to the potential for medical services to become overwhelmed and even collapse during the pandemic [61]. This potential was a more severe risk in Greenland and Iceland than in many other nations due to a shortage of critical care infrastructure, which is non-existent in most parts of these nations $[62,79]$. The inequitable distribution of funding in response to the pandemic and slowed distribution of the vaccine have similar, potentially negative consequences for the well-being of individuals and the pursuit of economic recovery [64,69]. Health-related risks extended beyond the macro and into the cosmic scale, presenting the possibility of existential crises. This was evidenced most prominently in Iceland via the rapid transmission of the virus in a care facility for geriatrics [61].

\subsection{Policy Responses to Mitigate the Scale of Systemic and Cosmic Scale Risk Events}

The identification of the types, categories and different scales of risk is helpful for understanding the reasoning behind various mitigation measures that have been adopted by the Icelandic and Greenlandic governments. Efforts have been undertaken in these nations to minimise the likelihood of a severe macro-scale event which might morph even further into cosmic-scale consequences. This has particularly concerned the recognition that critical healthcare infrastructure is limited and often remote. An overwhelmed and collapsed healthcare service would lead to disastrous consequences for the well-being of individuals and society alike. A bustling tourism sector during this crisis would have induced the greatest risk of such an event unfolding. Thus, in the case of Greenland, robust domestic policies have been enforced concerning restrictions on internal movement, whilst border policies have until recently prevented almost any international entry apart from for key workers. In Iceland, although restrictions on domestic movement have occasionally been implemented or advised, the border policy has been stringent, including double testing test and quarantining.

The Icelandic and Greenland approaches, whilst not 100\% effective in terms of preventing the spread of the virus by incomers, have been widely acclaimed, overall, to have been very effective. Iceland has been lauded for its approach to handling the virus, which has led the way in terms of the gathering of scientific evidence and its implementation in policies. Iceland has used the resources of deCODE, a private sector genetics firm located in Reykjavík, in tandem with the public health services to track the health of every individual in Iceland who has tested positive for the virus and, uniquely to this nation, sequenced the genetic material of each viral isolate and screened more than half of the nation's population for infection [80]. This information has informed the recommendations of the chief epidemiologist in Iceland concerning border controls and domestic restrictions. Unlike in similar island countries, such as New Zealand, Iceland never fully closed its borders to international tourists. This was thought to be mainly due to fears that the nation would become bankrupt without any tourism sector, a systemic risk of considerable magnitude [80]. 
The Greenlandic approach to border controls has been more stringent than Iceland. This appears to be partly due to the very limited critical care infrastructure in the countryeven in the capital of Nuuk there are only four intensive care beds [79]. However, the response of the Greenlandic government has also been to use the nation's isolation and historic resilience to its advantage, even in the weeks before the first domestic infection was confirmed $[38,79]$. In the first months of the pandemic, all internal air transportation was shut down, all citizens were advised to stay or remain at home, and no travel was permitted from one district to another unless a special license had been granted by the police or Greenland's epidemiological commission [79]. This approach to minimising macro and cosmic scale risks became even important in the early stages of the pandemic, when many nurses and other healthcare workers from Denmark cancelled arrangements to work in Greenland [38]. Indigenous practices and resilience have been reported as reinforcing the effectiveness of pandemic response and maintained cultural continuity [76]. Messaging of oral history and the passing down of knowledge through the generations has assisted in cultivating understanding in remote Arctic communities concerning the potential threats of the pandemic, which has been ballasted by the respect and esteem that is commonly held for local leaders. Moreover, fishing and harvesting activities in Greenland have continued during the pandemic, maintaining cultural integrity in the face of adversity, a hallmark of indigenous Arctic communities throughout history.

Despite some unavoidable negative economic consequences, the approaches in Greenland and Icelandic have been to provide support to ailing individuals and businesses in order to reduce the incidence of macro-scale impacts of a systemic character. Three financial aid packages that were introduced in Greenland in the first months of the pandemic, two of which were focused on the business sector and one on employees. The aid packages for the business sector consisted of an emergency package and a general package. The emergency package targeted private companies in the hotel and restaurant business as well as the service industry. Potential spillover impacts in other sectors were addressed in the general package, including the fishing industry, building and construction, and transportation sectors. There was a requirement for companies to be domiciled in Greenland in order to receive aid and only companies experiencing reductions in turnover of at least $30 \%$ qualified. The aid package for employees addressed wage compensation in the private sector. This was a furlough scheme whereby full wages would be covered by the Greenlandic government for all employees placed into sabbatical rather than made redundant. It applied to companies who would otherwise have dismissed at least $30 \%$ of employees or more than 25 employees [81].

No lockdown was ever imposed in Iceland, which potentially mitigated the scale of some of the economic impacts. Nevertheless, many businesses were placed under severe strain and it was necessary for the national government, municipalities and credit institutions to provide supportive measures to help individuals and companies survive the crisis. The Iceland Chamber of Commerce provides a detailed summary of the economic aid that was provided at the start of the pandemic in March and April 2020 [82]. Measures included the extension of deadlines for taxes, temporary reliefs for tourism businesses, support of part-time workers of up to $75 \%$ of salary, VAT refunds, state-backed bridging loans for businesses, support loans for small and medium-sized enterprises, subsidies for closed businesses, allowing 2020 losses to be offset against 2019 tax liabilities. Further government investment was provided later in April concerning violence, mental health, students and other social support. The Government of Greenland recognised the potential of this threat, especially towards women and in the light of the fact that it was a pre-existing societal problem, and temporarily banned sales of alcohol in Nuuk to try and minimise the potential for domestic violence [41].

The Icelandic response also recognized the interconnectedness of economic sectors. It has also been decidedly forward-thinking in nature, recognizing that the vulnerability of the nation was its overreliance on tourism, but that this sector would be crucial for generating economic recovery and avoiding the systemic and society-wide consequences of 
a national bankruptcy event akin to the national crisis of 2008. This was achieved through the temporary lifting of restrictions in 2020, allied to the stimulation of tourism demand via domestic and international marketing and tourism campaigns [77]. Similar marketing approaches have been adopted in 2021, albeit with more of a focus on attracting tourists from nations with high levels of vaccination, such as the United States [83]. This may lead to a faster than previously anticipated recovery for the sector.

\subsection{Island Advantages in Containing the Likelihood of Containing Systemic Risk}

It is easy to ascribe the very low number of COVID-19 cases and deaths in Greenland and Iceland purely to the nations' island status, which reduces the complexity of border management. Whilst this is correct and has also been attributed to the relative success of other nations at various times-examples such as New Zealand, Australia and Japan-this is too simplistic an explanation. One recent study found that a small geographical and population size did not provide the island nations of Cyprus, Iceland and Malta with any special advantages [35]. Isolation certainly assisted the Arctic states of Greenland and Iceland in enforcing very strict border policies. These were critical to the successful management of the pandemic, overall. Indeed, it was only when these were relaxed somewhat in Iceland during later summer 2020 that there was another sharp increase in positive COVID-19 cases and domestic rules on gathering and hygiene had to be tightened. However, the most important facets of successful virus containment in these Arctic states, which can provide lessons to other nation-states, were the adoption of a nationwide strategy which was considerate of the virus' characteristics, behaviour and transmission, and the trust shown by the public in following expert advice. In Greenland, PCR testing, isolation (especially of the vulnerable), quarantining and restrictions on movement were critical factors, but were also supported by the role of leaders in remote communities in communicating the potential severities of the pandemic. In the case of Iceland, the conducting of scientific research into the virus, including genetic sequencing, and its rapid incorporation in mitigation policies was also central to its success, allied to widespread public recognition about the importance of following expert advice.

\subsection{Limitations of the Paper}

The main challenge in conducting this research concerned the potential omission of impact data from Greenland, much of which is probably not reported in English but rather Greenlandic or Danish. Neither authors have any familiarity with the Greenlandic language and Danish is not their native tongue. It is possible that certain impacts have been widely reported in these languages and are severe; for example, the mental health effects of the pandemic or the challenges that immigrants face in coping with movement restrictions in remote communities in Greenland. In addition, some final economic data are not yet available with respect to Greenland for the year 2020, such as changes to GDP, unemployment, levels of bankruptcy and insolvency etc. In addition, the full economic impacts of the pandemic in Iceland and Greenland may only be fully appreciated in the aftermath of government economic aid-its withdrawal has the capacity to set in motion a spiral of unemployment unless conducted in tandem with the reopening of key sectors such as tourism.

\section{Conclusions}

This paper explored three research questions in the process of providing an in-depth exploration of the impacts and responses to the COVID-19 pandemic in Greenland and Iceland, two remote and isolated Arctic island nations that have nevertheless become economically dependent on the forces of globalization in the years prior to the virus. The nano-micro-meso-macro-cosmic framework was a useful tool for comprehending the scales of risk and the identification of types and sustainability categories of risk was facilitated through the development of an evaluative matrix for the Arctic in general, Iceland and Greenland. We find that the pandemic has presented risks in Iceland and 
Greenland across all scales, including to individuals, businesses, investors and industries. In addition, several of the risks were potentially of the systemic and cosmic scale. These included economic spillover effects, both direct and indirect, from tourism and related sectors, such as transportation, construction and entertainment.

The successful domestic policy responses of Iceland and Greenland have relevance to other nation-state contexts, even though many do not benefit from the same island advantages in terms of keeping the virus out. Iceland has endeavoured to straddle a thin line between discouraging entry to the nation and limiting the risks of virus transmission, whilst ensuring there was not a complete cessation of its tourism industry, which would harm the economy significantly. Greenland has taken an even stricter approach in terms of limiting domestic movement and entry to the nation, however, the scale of the nation, remoteness of many communities and very limited intensive care facilities appear to have left the government with little choice other than to pursue a 'health over wealth' approach. For policymakers and practitioners, the paper highlights successful risk mitigation and science-based measures that will be useful for any nation tackling a future pandemic, regardless of whether they are island states, Arctic nations or another country.

There are many options for future research deriving from this paper. Work should be carried out to quantify the economic effectiveness of the strategies of Iceland and Greenland in terms of limiting levels of unemployment, bankruptcy and macroeconomic decline, and the rapidity with which macroeconomic performance rebounds in the coming years. In addition, more research should be conducted into the impacts of the virus on the resilience and sustainability of remote communities in Iceland and Greenland, and the Arctic in general, to better understand local implications during and after the pandemic. This could include an exploration of the gender equity implications, since many of the Icelandic responses appeared, on the surface at least, to be more male orientated, e.g., economic support for infrastructure projects, the building sector, etc. Finally, the lessons learned from the largely successful management of the virus in Iceland and Greenland should be integrated into future global strategies for dealing with similar or even more severe pandemics.

Author Contributions: Conceptualization, D.C. and L.J.; methodology, D.C. and L.J.; validation, D.C. and L.J.; formal analysis, D.C. and L.J.; investigation, D.C. and L.J.; data curation, D.C. and L.J.; writing—original draft preparation, D.C.; writing—review and editing, D.C. and L.J.; visualization, D.C. and L.J.; supervision, L.J.; project administration, L.J. All authors have read and agreed to the published version of the manuscript.

Funding: This paper has been funded by NordForsk (grant number 76654) via their financial support to the Nordic Centre of Excellence ARCPATH (Arctic Climate Predictions-Pathways to Resilient, Sustainable Communities).

Acknowledgments: The authors were assisted in data collection by two graduate students enrolled in the University of Iceland's Environment and Natural Resources programme. They were Vincent Elijiah Merida and Kenneth Curtis Steele. We thank them very much for their contribution.

Conflicts of Interest: The authors declare no conflict of interest. The funders had no role in: the design of the study; the collection, analyses, or interpretation of data; the writing of the manuscript; or the decision to publish the results.

\section{References}

1. Larsen, J.N.; Petrov, A.N. The economy of the Arctic. In The Palgrave Handbook of Arctic Policy and Politics; Palgrave Macmillan: Cham, Switzerland, 2020; pp. 79-95.

2. Vammen Larsen, S.; Bors, E.K.; Jóhannsdóttir, L.; Gladun, E.; Gritsenko, D.; Nysten-Haarala, S.; Tulaeva, S.; Sformo, T. A Conceptual Framework of Arctic Economies for Policy-making, Research, and Practice. Glob. Policy 2019, 10, 686-696. [CrossRef]

3. Malinauskaite, L.; Cook, D.; Davíðsdóttir, B.; Ögmundardóttir, H.; Roman, J. Ecosystem services in the Arctic: A thematic review. Ecosyst. Serv. 2019, 36, 100898. [CrossRef]

4. Sisneros-Kidd, A.M.; Monz, C.; Hausner, V.; Schmidt, J.; Clark, D. Nature-based tourism, resource dependence, and resilience of Arctic communities: Framing complex issues in a changing environment. J. Sustain. Tour. 2019, 27, 1259-1276. [CrossRef]

5. Taarup-Esbensen, J. A Resilience-Based Approach to Risk Assessments-Building Resilient Organizations under Arctic Conditions. Risk Anal. 2020, 40, 2399-2412. [CrossRef] [PubMed] 
6. Falardeau, M.; Bennett, E.M. Towards integrated knowledge of climate change in Arctic marine systems: A systematic literature review of multidisciplinary research. Arct. Sci 2019, 6, 1-23. [CrossRef]

7. Hausner, V.; Trainor, S.; Ford, J.; Nikitina, E.; Klokov, K.; Cook, D.; Stammler, F.; Fauchald, P.; Nilsson, L.M. Impacts of Climate Change and Climate Extremes on Arctic Livelihoods and Communities. Chapter 7 of Climate Issues of Concern; Arctic Monitoring and Assessment Programme (AMAP): Tromso, Norway, 2021; in press.

8. O'Garra, T. Economic value of ecosystem services, minerals and oil in a melting Arctic: A preliminary assessment. Ecosyst. Serv. 2017, 24, 180-186. [CrossRef]

9. Christensen, T.R.; Lund, M.; Skov, K.; Abermann, J.; Lopez-Blanco, E.; Scheller, J.; Scheel, M.; Jackowicz-Korczynski, M.; Langley, K.; Murphy, M.J.; et al. Multiple Ecosystem Effects of Extreme Weather Events in the Arctic. Ecosystems 2021, 24, 122-136. [CrossRef]

10. Waits, A.; Emelyanova, A.; Oksanen, A.; Abass, K.; Rautio, A. Human infectious diseases and the changing climate in the Arctic. Environ. Int. 2018, 121, 703-713. [CrossRef] [PubMed]

11. Korchak, E.A.; Serova, N.A.; Emelyanova, E.E.; Yakovchuk, A.A. Human capital of the Arctic: Problems and development prospects. In IOP Conference Series: Earth and Environmental Science; IOP Publishing: Bristol, UK, 2019; Volume 302, p. 012078.

12. Jóhannsdóttir, L.; Cook, D. Systemic risk of maritime-related oil spills viewed from an Arctic and insurance perspective. Ocean Coast. Manag. 2019, 179, 104853. [CrossRef]

13. Jóhannsdóttir, L.; Cook, D.; Arruda, G.M. Systemic risk of cruise ships viewed from an Arctic and insurance perspective. Elem.-Sci. Anthr. 2021, in press. [CrossRef]

14. COVID-19 Risks Outlook: A Preliminary Mapping and Its Implications. Available online: https://www.weforum.org/reports/ covid-19-risks-outlook-a-preliminary-mapping-and-its-implications (accessed on 26 October 2020).

15. Larsen, J.N.; Fondahl, G. Arctic human development report. In Human Development; Stefansson Arctic Institute: Akureyri, Iceland, 2015; Volume 2.

16. Baumöhl, E.; Bouri, E.; Hoang, T.H.V.; Shahzad, S.J.H.; Výrost, T. Increasing Systemic Risk during the Covid-19 Pandemic: A Cross-Quantilogram Analysis of the Banking Sector; Leibniz Information Centre for Economics: Kiel, Germany, 2020.

17. Lai, Y.; Hu, Y. A study of systemic risk of global stock markets under COVID-19 based on complex financial networks. Physica A 2020, 566, 125613. [CrossRef]

18. Rizwan, M.S.; Ahmad, G.; Ashraf, D. Systemic Risk: The Impact of COVID-19. Financ. Res. Lett. 2020, 36, 101682. [CrossRef] [PubMed]

19. Meeting the Future: Dynamic Risk Management for Uncertain Times. Available online: https://www.mckinsey.com/businessfunctions / risk/our-insights / meeting-the-future-dynamic-risk-management-for-uncertain-times?cid=other-eml-alt-mipmck\&hdpid=c860275d-5a3d-46bb-9d2a-937bf278e11b\&hctky=3010333\&hlkid=efbb4508568941c5ad93822837368e30\# (accessed on 18 May 2021).

20. Human Development Report 2020: The Next Frontier-Human Development and the Anthropocene. Available online: http: / /hdr.undp.org/en/2020-report (accessed on 31 May 2021).

21. COVID-19 Coronavirus Pandemic. Available online: https://www.worldometers.info/coronavirus/ (accessed on 31 May 2021).

22. Covid Cases Reported in Antarctic for First Time-Reports. Available online: https://www.theguardian.com/world/2020/dec/ 22/ covid-cases-recorded-in-antarctica-for-first-time (accessed on 8 January 2021).

23. COVID-19 Storm Engulfs Mount Everest. Available online: https://www.channelnewsasia.com/news/asia/covid-19-outbreaknepal-mount-everest-base-camp-climbers-14909296 (accessed on 31 May 2021).

24. Sumner, A.; Hoy, C.; Ortiz-Juarez, E. Estimates of the Impact of COVID-19 on Global Poverty. United Nations Working Paper 2020/43. Available online: https://www.wider.unu.edu/publication/estimates-impact-covid-19-global-poverty (accessed on 8 January 2021).

25. Intergovernmental Panel on Climate Change (IPCC). Global Warming of $1.5{ }^{\circ} \mathrm{C}$-Summary for Policymakers. [IPCC SR1.5]. Geneva, Working Groups I, II and III of the Intergovernmental Panel on Climate Change. Available online: https://www.ipcc.ch/ 2018/10/08/summary-for-policymakers-of-ipcc-special-report-on-global-warming-of-1-5c-approved-by-governments/ (accessed on 1 June 2021).

26. Schwarcz, S.L. Systemic risk. Georget. Law J. 2008, 97, 193-249.

27. Baue, B. Blueprint 3. Data Integration, Contextualization E Activation for Multicapital Accounting; Blueprint Series 2016-2018; Reporting 3.0; Berlin, Germany, 2017, Available online: https:/ /www.r3-0.org/blueprint-3-data/ (accessed on 28 July 2021).

28. Burckart, W.; Lydenberg, S.; Ziegler, J. Tipping Points 2016: Summary of 50 Asset Owners' and Managers' Approaches to Investing in Global Systems; The Investment Integration Project and Investor Responsibility Research Center Institute: New York, NY, USA, 2016.

29. PwC. Environmental Systemic Risk \& Insurance White Paper; WWF-UK \& RSA Group PLC: London, UK, 2014.

30. Zhang, Z. Modeling and Analyzing Systemic Risk in Complex Sociotechnical Systems: The Role of Teleology, Feedback, and Emergence. Ph.D. Thesis, Columbia University, New York, NY, USA, 2018.

31. Thurm, R.; Baue, B.; van der Lugt, C. Blueprint 5 The Transformation Journey: A Step-by-Step Approach to Organizational Thriveability and System Value Creation; Reporting 3.0.; Berlin, Germany, 2018. Available online: https://www.r3-0.org/blueprint-3-data/ (accessed on 28 July 2021).

32. Policy Response for Iceland. Available online: https:// www.covid19healthsystem.org/countries/iceland/livinghit.aspx?Section= 2.1\%20Physical\%20infrastructure\&Type=Section (accessed on 31 May 2021).

33. COVID-19 in Iceland-Statistics. Available online: https:/ / www.covid.is/ data (accessed on 17 May 2021). 
34. Balmford, B.; Annan, J.D.; Hargreaves, J.C.; Altoè, M.; Bateman, I.J. Cross-country comparisons of COVID-19: Policy, politics and the price of life. Environ. Resour. Econ. 2020, 76, 525-551. [CrossRef] [PubMed]

35. Cuschieri, S.; Pallari, E.; Hatziyianni, A.; Sigurvinsdottir, R.; Sigfusdottir, I.D.; Sigurðardóttir, Á.K. Mortality comparisons of COVID-19 with all-cause and non-communicable diseases in Cyprus, Iceland and Malta: Lessons learned and forward planning. Public Health 2021, in press. [CrossRef]

36. A Simplified Guide to Iceland's COVID-19 Rules. Available online: https://icelandmonitor.mbl.is/news/news/2021/05/17/a_ simplified_guide_to_iceland_s_covid_19_travel_rul/ (accessed on 18 May 2021).

37. Maps in Support of the Council Recommendation on a Coordinated Approach to Travel Measures in the EU. Available online: https:/ / www.ecdc.europa.eu/en/covid-19/situation-updates/weekly-maps-coordinated-restriction-free-movement (accessed on 18 May 2021).

38. A Tough Strategy of Isolation Has Protected Greenland from Coronavirus-So Far. Available online: https:/ /www.arctictoday. com/a-tough-strategy-of-isolation-has-protected-greenland-from-coronavirus-so-far/ (accessed on 18 May 2021).

39. Greenland: Authorities in Greenland Maintaining COVID-19-Related Restrictions as of April 9/Update 8. Available online: https: / / www.garda.com/crisis24/news-alerts/468936/greenland-authorities-in-greenland-maintaining-covid-19-relatedrestrictions-as-of-april-19-update-8 (accessed on 18 May 2021).

40. Grønland har Kun Fire Intensivpladset-Alligevel er Landets Coronia-General Optimistik. Available online: https: / / xn--jyllandsposten-d72h.dk/indland/ECE12031791/groenland $\%$ E2\%80\%90har $\%$ E2\%80\%90kun $\%$ E2\%80\%90fire $\%$ E2\%80\% 90intensivpladser\%E2\%80\%90alligevel\%E2\%80\%90er\%E2\%80\%90landets $\%$ E2 $\% 80 \% 90$ coronageneral $\%$ E2\%80\%90optimistisk (accessed on 18 May 2021).

41. Greenland: Local Government Temporarily Prohibits Sale of Alcohol during Coronavirus Outbreak. Available online: https: / / www.loc.gov /law / foreign-news/article/greenland-local-government-temporarily-prohibits-sale-of-alcohol-duringcoronavirus-outbreak/\#: \{\}:text=(Mar.,Nuuk\%2C\%20Kapisillit\%2C\%20and\%20Qeqertarsuatsiaat (accessed on 18 May 2021).

42. Coronavirus-Frequently Asked Questions. Available online: https://visitgreenland.com/corona-faq/\#enter (accessed on 18 May 2021).

43. Harðar Sóttvarnarráðstafanir í Nuuk í kjölfar Sex Smita Strict Infection Controls in Nuuk Following Six Infections. Available online: https: / / www.ruv.is/frett/2021/05/29/hardar-sottvarnarradstafanir-i-nuuk-i-kjolfar-sex-smita (accessed on 31 May 2021).

44. Cook, D.; Malinauskaite, L.; Davíðsdóttir, B.; Ögmundardóttir, H. Co-production processes underlying the ecosystem services of glaciers and adaptive management in the era of climate change. Ecosyst. Serv. 2021, in press. [CrossRef]

45. Cook, D.; Fazeli, R.; Davíðsdóttir, B. The need for integrated valuation tools to support decision-making-The case of cultural ecosystem services sourced from geothermal areas. Ecosyst. Serv. 2019, 37, 100923. [CrossRef]

46. Gunnarsdóttir, I.; Davidsdottir, B.; Worrell, E.; Sigurgeirsdóttir, S. Review of indicators for sustainable energy development. Renew. Sustain. Energy Rev. 2020, 133, 110294. [CrossRef]

47. The Coronavirus in the Arctic: Spotlight on Mental Health. Available online: https://arctic-council.org/en/news/thecoronavirus-in-the-arctic-spotlight-on-mental-health/ (accessed on 19 May 2021).

48. Seasonally Adjusted Unemployment Rate. Available online: https://statice.is/publications/news-archive/labour-market/thelabour-market-in-january-2021/\#: \{\}:text=The\%20rate\%20of\%20employed $\% 20$ individuals,or\%2023.9\%25\%20of $\% 20$ the $\% 20$ population (accessed on 19 May 2021).

49. Shocking Unemployment Rates in Parts of Iceland. Available online: https://icelandmonitor.mbl.is/news/news/2020/10/14 /shocking_unemployment_rates_in_parts_of_iceland/ (accessed on 19 May 2021).

50. Erlendir Borgarar og Ungt Fólk Tekið Pungt Högg í Faraldrinum [Foreigners and Young People the Hardest Hit during the Pandemic]. Available online: https://www.visir.is/g/20202025359d/erlendir-borgarar-og-ungt-folk-tekid-thungt-hogg-ifaraldrinum (accessed on 19 May 2021).

51. Numbers of Foreign Visitors. Available online: https://www.ferdamalastofa.is/en/recearch-and-statistics/numbers-of-foreignvisitors (accessed on 19 May 2021).

52. Going for Growth 2021—Iceland. Available online: https://www.oecd.org/economy/iceland-economic-snapshot/ (accessed on 19 May 2021).

53. Greenland's Economy Autumn 2020. Available online: https://naalakkersuisut.gl/ \{\}/media/Nanoq/Files/Attached\%20Files / Finans/ENG/GOR_ny/G\%C3\%98R\%20rapport\%202020\%20en.pdf (accessed on 21 May 2021).

54. Annual Report-Air Greenland A/S 2020. Available online: https://www.airgreenland.com/media/1538831/arsrapportmaster_eng_web.pdf (accessed on 21 May 2021).

55. Prepare for the Worst, Greenland Tourism Industry Warned. Available online: https://nunatsiaq.com/stories/article/preparefor-the-worst-greenland-tourism-industry-warned/ (accessed on 21 May 2021).

56. Fly-In Fly-Out Workers in the Arctic: The Need for More Workforce Transparency in the Arctic. Available online: https: / / www.thearcticinstitute.org/fly-in-fly-out-workers-arctic-need-workforce-transparency-arctic/ (accessed on 21 May 2021).

57. Verslunum Geysis lokað og Öllum Sagt Upp [Geysir Shops Closed and All Staff Let Go]. Available online: https: / www.visir.is/ g/20212068462d/uppsagnir-og-lokanir-hja-geysi (accessed on 19 May 2021).

58. Deserted Buildings on Laugavegur: Video. Available online: https://icelandmonitor.mbl.is/news/news/2020/10/12/deserted_ buildings_on_laugavegur_video/(accessed on 19 May 2021). 
59. Deloitte Economics' Coronavirus Impact Monitor. What Are the Impacts of the Coronavirus on the Greenlandic Fishing Industry? Available online: https://www2.deloitte.com/content/dam/Deloitte/dk/Documents/audit/Corona\%20impact\%20monitor\% 20-\%20Greenland\%20-\%2027052020.pdf (accessed on 27 July 2021).

60. Reduced First-Half Sales for Iceland Seafood International, but Some COVID Recovery Seen. Available online: https: //www.seafoodsource.com/news/business-finance/reduced-first-half-sales-for-iceland-seafood-international-but-somecovid-recovery-seen (accessed on 21 May 2021).

61. Landspítalinn á Neyðarstig [University Hospital under Emergency Protocols]. Available online: https://www.mbl.is/frettir/ innlent/2020/10/25/landspitalinn_a_neydarstig/(accessed on 19 May 2021).

62. Birtir til á Bergi Eftir að Liðsauki Barst að Sunnan [Reinforcements Arrive from the South to Staff Berg]. Available online: https:/ / www.visir.is/g/2020141042d/birtir-til-a-bergi-eftir-ad-lidsauki-barst-ad-sunnan (accessed on 19 May 2021).

63. Vaccinationsudrulning Forsinkes [Vaccination Rollout Is Delayed]. Available online: https://sermitsiaq.ag/vaccinationsudrulningforsinkes (accessed on 21 May 2021).

64. Covid-19 in the Arctic: Briefing Document for Senior Arctic Officials. Available online: https://www.unak.is/static/files/pdfskjol/2020/covid-19-in-the-arctic-briefing-to-saos_for-public-release.pdf (accessed on 19 May 2021).

65. Pan-Arctic Report: Gender Equality in the Arctic-Phase 3. Sustainable Development Working Group of the Arctic Council. Available online: https: / / arcticgenderequality.network/phase-3 (accessed on 28 May 2021).

66. Why Domestic Violence in the Arctic Could Surge with the Coronavirus Pandemic. Available online: https://www.arctictoday. com/why-domestic-violence-in-the-arctic-could-surge-with-the-coronavirus-pandemic/ (accessed on 28 May 2021).

67. The Misogynist Violence of Iceland's Feminist Paradise. Available online: https://foreignpolicy.com/2020/07/15/themisogynist-violence-of-icelands-feminist-paradise/ (accessed on 28 May 2021).

68. Foreign Affairs Minister Calls Xenophobic Infection Shaming “Unsparing and Unfair”. Available online: https://www. icelandreview.com/politics / foreign-affairs-minister-calls-xenophobic-infection-shaming-unsparing-and-unfair/ (accessed on 31 May 2021).

69. Coronavirus in the Arctic: A Stress Test. Available online: https://arctic-council.org/en/news/coronavirus-in-the-arctic-astress-test/ (accessed on 21 May 2021).

70. IA: Vi Mangler Information om Coronavirus pa Grønlandsk [IA: We Lack Information about the Coronavirus in Greenlandic] Available online: https:/ / sermitsiaq.ag/iamangler-information-coronavirus-groenlandsk (accessed on 21 May 2021).

71. Opponents of a Major Greenland Mine Says Coronavirus Constraints Are Compromising the Public Hearing Process. Available online: https:/ / www.arctictoday.com/opponents-of-a-major-greenland-mine-say-coronavirus-constraints-are-compromisingthe-public-hearing-process / (accessed on 21 May 2021).

72. COVID-19: How the Virus Has Frozen Arctic Research. Available online: https://www.thearcticinstitute.org/covid-19-virusfrozen-arctic-research/ (accessed on 21 May 2021).

73. Arctic Circle Assembly Will Cancel 2020 Gathering Because of COVID-19. Available online: https://www.arctictoday.com/arcticcircle-assembly-will-cancel-2020-gathering-because-of-covid-19/ (accessed on 19 May 2021).

74. The COVID-19 Pandemic Has Halted Most US Arctic Field Research for 2020. Available online: https:/ / www.arctictoday.com/ the-covid-19-pandemic-has-halted-most-us-arctic-field-research-for-2020/ (accessed on 27 July 2021).

75. Coronavirus Puts Arctic Climate Research on Hold. Available online: https:/ / www.dw.com/en/coronavirus-puts-arctic-climatechange-research-on-ice/a-53061086 (accessed on 19 May 2021).

76. The Impact of COVID-19 on Inuit Communities. Available online: https://arctic-council.org/en/news/the-impact-of-covid-19 -on-inuit-communities / (accessed on 28 May 2021).

77. Virtual Session with Iceland's Economic Council. Available online: https://www.oecd.org/economy/virtual-session-withicelands-economic-council-june-2020.htm (accessed on 28 May 2021).

78. Greenland and Iceland in the New Arctic—Recommendations of the Greenland Committee Appointed by the Minister for Foreign Affairs and International Development Co-Operation. Available online: https://www.government.is/library/01-Ministries / Ministry-for-Foreign-Affairs/PDF-skjol/Greenland-Iceland-rafraen20-01-21.pdf (accessed on 31 May 2021).

79. 'Stay at Home'. Greenland Authorities Tell Travellers. Available online: https://www.arctictoday.com/stay-at-home-greenlandauthorities-tell-travellers/ (accessed on 28 May 2021).

80. Scudellari, M. How Iceland hammered COVID with science. Nature 2020, 587, 536-539. [CrossRef] [PubMed]

81. COVID-19-Aid Packages to Companies and Employees in Greenland. Available online: https://www.nuna-law.com/2020/03/ 29/covid-19-corona-aid-packages-to-companies-and-employees-in-greenland/?lang=en (accessed on 31 May 2021).

82. The Icelandic Economy 2020. Available online: https://www.government.is/library/09-Embassies/New-York-Consulate/ ICEEcon2020-210920-Web_Final.pdf (accessed on 31 May 2021).

83. The Start of a New Tourist Season? Available online: https://grapevine.is/news/2021/05/03/the-start-of-a-new-tourist-season/ (accessed on 27 July 2021). 